\title{
Effect of Barberry Eradication on Changes in Populations of Puccinia graminis in Minnesota
}

P. D. Peterson, Clemson University, Pee Dee Research and Education Center, Florence, SC 29506; K. J. Leonard, University of Minnesota, Department of Plant Pathology, St. Paul 55108; A. P. Roelfs, (retired) United States Department of Agriculture-Agricultural Research Service Cereal Disease Laboratory, St. Paul, MN 55108; and T. B. Sutton, North Carolina State University, Department of Plant Pathology, Raleigh 27695

\begin{abstract}
Peterson, P. D., Leonard, K. J., Roelfs, A. P., and Sutton, T. B. 2005. Effect of barberry eradication on changes in populations of Puccinia graminis in Minnesota. Plant Dis. 89:935-940.

Proportions of formae speciales of Puccinia graminis in collections of aeciospores from barberry were determined from cereal rust survey records from 1912 to 2002 in Minnesota. The frequency of $P$. graminis f. sp. avenae in aeciospore collections fluctuated between 0 and $10 \%$ from 1920 to 2002, even though oat was the dominant small grain crop in Minnesota until 1970. In early years, $P$. graminis f. sp. tritici was common, but the frequency of $P$. graminis $\mathrm{f}$. sp. tritici in aeciospore collections declined to a low of $4 \%$ in the 1980 s, whereas $P$. graminis f. sp. secalis increased to $96 \%$. After 1990, the frequency of $P$. graminis f. sp. tritici increased and $P$. graminis f. sp. secalis declined in aecial collections, possibly indicating a changing proportion of $P$. graminis f. sp. secalis and tritici on wild grasses near barberry bushes. Diversity of races among uredinial collections of $P$. graminis f. sp. tritici from wheat in Minnesota declined sharply from 1912 to 1930 and remained low to 2002. Although the races of $P$. graminis f. sp. tritici most common in uredinial collections also were most common in the aecial collections in five of nine decades from 1912 to 1999 as well in the years 2000 to 2002, the diversity of races was greater among aecial than uredinial collections. Diversity in aecial collections remained nearly constant for 90 years, indicating a continuing contribution of the sexual stage to diversity of $P$. graminis $\mathrm{f}$. sp. tritici.
\end{abstract}

The relationship between the common barberry (Berberis vulgaris Pers.) and the stem rust pathogen, Puccinia graminis L., is one of the classic host-pathogen interactions in plant pathology. As the alternate host of $P$. graminis, barberry is the key in the sexual stage of the pathogen's life cycle in the northern United States. Because conditions typically are too severe in the northern states for $P$. graminis to survive as uredinial infections through the winter, barberry enables the pathogen to survive locally by providing a host for basidiospores produced from overwintering telia (2). In turn, barberry serves as the source of local, initial inoculum through the production of aeciospores in large enough numbers to initiate local epidemics, leading directly to the production of urediniospores and regional stem rust epidemics. Finally, barberry is the site of sexual reproduction for $P$. graminis. Sexual recom-

Corresponding author: P. D. Peterson

E-mail: ppeters@clemson.edu

This research was supported in part by the USDAARS Cereal Disease Laboratory, St. Paul, MN 55108.

Accepted for publication 26 April 2005

DOI: 10.1094/PD-89-0935

(C) 2005 The American Phytopathological Society bination on barberry is the major source of new combinations of virulence genes in the pathogen population, which can result in the development of new pathogen genotypes capable of attacking grain cultivars lacking effective rust resistance (13).

Eradication of the alternate host has been considered an important step in controlling epidemics of stem rust (13). Between 1918 and 1980, over 500 million barberry bushes were destroyed from major wheat-producing states in the United States during the cooperative federal-state Barberry Eradication Program (13). Eradication of barberry is credited with disrupting the life cycle of $P$. graminis, thus eliminating initial inoculum and reducing early, local epidemics of stem rust $(13,18)$. A delay in the onset of disease by at least 10 days, a reduction in pathogen genetic variability, and the stabilization of pathogen races also is attributed to the removal of the alternate host (13). Barberry eradication combined with the successful deployment of genetic resistance in wheat cultivars and breeding earlier-maturing winter wheat cultivars for the central Great Plains have been credited with reducing stem rust to a minor problem over the last half century.

Federal funding for the Barberry Eradication Program was eliminated by 1980 , causing some scientists and field personnel to voice concerns over the possible re- emergence of barberry and its effects on the resurgence of stem rust epidemics (10). The potential for barberry to make a comeback in the north-central United States could allow the sexual cycle of $P$. graminis to become reestablished (7). Evidence of barberry bushes reemerging has been found in several states, including Minnesota (11), a state heavily involved in the Barberry Eradication Program throughout the twentieth century.

Studies have been conducted which examine the race diversity in asexual $P$. graminis populations $(2,4,5,9,14)$ and sexual $P$. graminis populations $(4,14)$. However, no studies have compared diversity among sexual and asexual populations of $P$. graminis with respect to barberry eradication. Evaluating changes in population diversity at both a forma speciales level and a race level may help provide insights into the potential role of barberry in future stem rust epidemics if barberry is allowed to spread. Using Minnesota as a case study, the objectives of this study were to document the effect of barberry removal in altering the $P$. graminis population structure by (i) evaluating data on aecial isolates of $P$. graminis collected from barberry and identifying changes in population structure before, during, and after barberry eradication, and (ii) comparing aecial and uredinial populations of $P$. graminis f. sp. tritici to determine differences in population complexity and race structure over a 90 -year period.

\section{MATERIALS AND METHODS}

Historical data of aecial collections from barberry made from 1912 to 1998 in Minnesota were located among the records of the Barberry Eradication Program located in the University of Minnesota Archives, and these data were used as a basis for this study. All historical aecial collections were made by personnel or collaborators of the Cereal Disease Laboratory (CDL) (formerly the Cooperative Rust Laboratory and the Cereal Rust Laboratory [CRL]), and classification of aecial isolates into formae speciales and races also was done there. The authors made additional collections of infected barberry leaves between 1998 and 2002 that were characterized at the CDL using the same methods (20).

Identifications to the forma speciales level had been obtained by collecting sam- 
ples and testing their ability to infect different host species, including oat, wheat, and rye. Samples were identified as $P$. graminis f. sp. avenae, $P$. graminis f. sp. tritici, $P$. graminis f. sp. secalis, or $P$. graminis $\mathrm{f}$. sp. 'unknown'. $P$. graminis $\mathrm{f}$. sp. 'unknown' samples were identified as $P$. graminis, which failed to infect any of the test hosts either because the cultures were of $P$. graminis f. sp. agrostidis, phleipratensis, and poae (3), which do not infect cereals, or because the aeciospores may have been nonviable. These samples were disregarded from the data analysis. Samples of $P$. graminis f. sp. tritici were further differentiated into races using a set of 12 different wheat species encompassing Triticum aestivum, . compactum $(=T$. aestivum var. compactum), T. durum (=T. turgidum var. durum), T. monococcum (= T. monococcum var. monococcum), and $T$. diccoccum ( $=$ T. turgidum var. diccoccum) selected by E. C. Stakman in 1917 (19). This set of lines later was referred to as the "standard differential varieties" (20). Although other differentials and new race nomenclature were used later in the survey process, care was taken to ensure continuity by establishing connections between Stakman races with the older differential set and the CRL races defined with the newer set. For the purpose of this study, all race designations were translated back to the original standard differential designations (14-16). In some cases, isolates were identified as $P$. graminis $\mathrm{f}$. sp. tritici isolates, but their race designation was not defined (i.e., their reaction on the standard differentials was too ambiguous to be conclusive). These isolates were not included in the analysis. Also, some collections identified as $P$. graminis f. sp. tritici were found to contain more than a single race when single-pustule isolates were made. Data were recorded for isolates derived from the initial screening to identify formae speciales and from virulence tests to determine races of $P$. graminis f. sp. tritici. Thus, a single aecial collection might be shown to contain two or more formae speciales or two or more races of $P$. graminis f. sp. tritici, each of which would be defined as a separate isolate. All such isolates

Table 1. Percentage of isolates of each forma speciales of Puccinia graminis identified among aecial collections from barberry in Minnesota, 1912 to 2002

\begin{tabular}{lcccc}
\hline & & \multicolumn{3}{c}{ Total collections identified (\%) for P. graminis f. sp. } \\
\cline { 3 - 5 } Dates & No. of collections & avenae & secalis & tritici \\
\hline $1912-1919$ & 7 & 14.3 & 28.6 & 57.1 \\
$1920-1929$ & 106 & 1.9 & 74.5 & 23.6 \\
$1930-1939$ & 404 & 4.5 & 38.9 & 56.7 \\
$1940-1949$ & 25 & 4.0 & 64.0 & 32.0 \\
$1950-1959$ & 55 & 0.0 & 67.3 & 32.7 \\
$1960-1969$ & 67 & 10.5 & 55.2 & 34.3 \\
$1970-1979$ & 43 & 2.3 & 79.1 & 18.6 \\
$1980-1989$ & 66 & 0.0 & 95.5 & 4.5 \\
$1990-1999$ & 36 & 0.0 & 38.9 & 100.1 \\
$2000-2002$ & 17 & 0.0 & 0.0 & 357 \\
Total no. of isolates & 826 & 30 & 439 & \\
\hline
\end{tabular}

were included in the analysis, which accounts for the numbers of isolates sometimes being larger than the number of collections.

Data on uredinial isolates collected from infected wheat also were obtained from the records of the CDL. Data from 1939 to 1990 have been published annually and data from earlier years were located among United States Department of Agriculture files held at the CDL. Data from 1970 to 1973 were unavailable and, therefore, not included in the analysis. According to procedures outlined in Barberry Eradication records, data on the race structure of the $P$. graminis f. sp. tritici isolates from wheat were obtained in a similar way to that of the aecial isolates. Infected wheat leaves were collected and urediniospores from rust pustules were used to inoculate a set of standard differentials (5). Races were determined according to the response on the set of standard differentials containing different major genes for resistance to P. graminis f. sp. tritici.

In addition to basic descriptive comparisons of the data from both uredinial and aecial populations, the data also were characterized using the normalized Shannon Index of Diversity $(5,17), H_{\mathrm{w}}=-\Sigma_{\mathrm{i}} p_{\mathrm{i}}$ $\ln \left(p_{\mathrm{i}}\right) / \ln n$, where $p_{\mathrm{i}}=$ the frequency of the $i$ th phenotype and $n$ is the number of different individuals (isolates) in the population. This index characterizes populations by using a measure of the number of individuals in a population and the evenness of distribution of individuals throughout a population. Shannon Index of Diversity has been used frequently in plant pathology to characterize intraspecific diversity in plant pathogens $(4,6)$. Because the number of aecial isolates per decade (usually about 20) was much fewer than the number of uredinial isolates, we also calculated an adjusted normalized Shannon Index for uredinial populations, which was adjusted to an equivalent size of 20 uredinial isolates per decade. This was done by selecting 20 uredinial isolates at random from the total for each decade and calculating an adjusted normalized Shannon Index. The random sampling was repeated to yield five independent simulation runs per dec- ade, and the adjusted normalized Shannon Index for uredinial populations was calculated as the mean value over the five randomly selected sets of 20 isolates for each decade.

\section{RESULTS}

Data on formae speciales of $P$. graminis found in samples of aecia collected in Minnesota from 1912 to 2002 are summarized in Table 1. There were 826 samples (not including those characterized as $P$. graminis f. sp. 'unknown') that were identified to forma speciales level during the 90 years of the survey, with 517 of those samples made during the first three decades of the Barberry Eradication Program (1912 to 1939). In the analysis of formae speciales diversity, an aecial sample was considered to contain two isolates if the sample was shown to include two different formae speciales. In all, 404 isolates were identified in the 1930s alone, a period of intensive barberry survey work (10). As more barberry bushes were eradicated, the numbers of isolates identified declined in decades after 1940 (Table 1). Although numbers of isolates collected depended on the importance of the program and the resources available to collect and identify these isolates, these numbers also relate to the declining frequency of epidemics of stem rust from the 1940s onward (13).

Overall, during the 90-year survey, the dominant forma speciales found among aecial isolates was $P$. graminis f. sp. secalis (Table 1). Of the isolates collected, $439(53 \%)$ were identified as $P$. graminis f. sp. secalis. Only a few aecial collections were made before 1920, but most of them were identified as $P$. graminis f. sp. tritici. In the $1920 \mathrm{~s}$, most aecial isolates were identified as $P$. graminis f. sp. secalis; however, in the $1930 \mathrm{~s}$, the majority were $P$. graminis f. sp. tritici. From the 1940s until the 1980s, $P$. graminis f. sp. tritici isolates composed less than $35 \%$ of the total number for any given decade. This situation changed in the 1990s and from 2000 to 2002. Among the isolates collected during the 1990s, 61\% were P. graminis f. sp. tritici and the remaining $39 \%$ were identified as $P$. graminis f. sp. secalis. All isolates collected since 2000 were identified as $P$. graminis f. sp. tritici.

The race structure of the aecial $P$. graminis f. sp. tritici isolates fluctuated throughout the course of the survey (Table 2 ). Race diversity and the predominant races collected also changed over time. From the 357 aecial samples identified as P. graminis f. sp. tritici, 426 isolates were classified into 52 different races, with the greatest number of isolates (19\%) identified as race 56 . The largest overall number of isolates (284 isolates) and the greatest diversity of $P$. graminis f. sp. tritici races (38 races) were identified between 1930 and 1939 (Table 2). However, the most predominant race found among aecial 
isolates during this decade was race 56 , occurring at a frequency of $24 \%$.

Often, the races most commonly identified among aecial samples of $P$. graminis $\mathrm{f}$. sp. tritici also were most common in the uredinial isolates collected during the same decade (Table 3). For example, the most common races were the same for both aecial and uredinial collections from the 1920s, 1930s, 1940s, 1960s, 1970s, and the years 2000 to 2002 . In the 1980 s and from 1912 to 1919 , there were too few aecial isolates for a meaningful comparison. When the three most common races are compared by decade for aecial and uredinial collections, half of the top three races in aecial isolates are also among the top three races in uredinial collections. If the years 1912 to 1919 and 1980 to 1989 are excluded from the comparison because of few aecial isolates, there is an overlap between the three most common races in aecial and uredinial collections in more than half the cases. Some races appeared in the three most common races consistently from 1912 to 2002. Race 11 was among the three most common races in 6 of the 10 decades for aecial collections and in 5 decades for uredinial collections. Race 15 was among the three most common races in five decades for aecial collections and in six decades for uredinial collections. Interestingly, both race 11 and race 15 were common among aecial collections before they were common among uredinial collections (Table 3). Of the 52 races identified in aecial collections, 20 were found only once (Table 2).

Of the 42 races identified in uredinial collections, 4 were found only once, and 27 of the 42 races were found in two or more decades. Race 294, which was the third most common race from 1990 to 1999 , had not been identified previously in Minnesota (Table 4).

Table 2. Numbers of isolates and races of Puccinia graminis f. sp. tritici found per decade in aecial collections from barberry in Minnesota from 1912 to 2002

\begin{tabular}{|c|c|c|c|c|c|c|c|c|c|c|c|}
\hline \multirow[b]{2}{*}{ Race } & \multicolumn{10}{|c|}{ Decade } & \multirow[b]{2}{*}{ Total } \\
\hline & 1912-1919 & 1920-1929 & 1930-1939 & 1940-1949 & 1950-1959 & 1960-1969 & 1970-1979 & 1980-1989 & 1990-1999 & 2000-2002 & \\
\hline 10 & $\ldots$ & $\ldots$ & 2 & $\ldots$ & $\ldots$ & $\ldots$ & $\ldots$ & $\ldots$ & $\ldots$ & $\ldots$ & 2 \\
\hline 11 & 1 & $\ldots$ & 29 & 1 & 4 & 3 & 1 & $\ldots$ & 6 & 3 & 48 \\
\hline 14 & $\ldots$ & $\ldots$ & 5 & $\ldots$ & $\ldots$ & $\ldots$ & $\ldots$ & $\ldots$ & $\ldots$ & $\ldots$ & 5 \\
\hline 15 & $\ldots$ & $\ldots$ & 4 & 3 & 6 & 11 & 5 & $\ldots$ & 1 & 2 & 32 \\
\hline 16 & $\ldots$ & $\ldots$ & 2 & $\ldots$ & $\ldots$ & $\ldots$ & $\ldots$ & $\ldots$ & 2 & 2 & 6 \\
\hline 17 & 1 & 1 & 36 & 3 & $\ldots$ & 3 & $\ldots$ & $\ldots$ & $\ldots$ & $\ldots$ & 44 \\
\hline 19 & 1 & $\ldots$ & 2 & $\ldots$ & $\ldots$ & $\ldots$ & $\ldots$ & $\ldots$ & $\ldots$ & $\ldots$ & 3 \\
\hline 21 & $\ldots$ & 1 & 14 & $\ldots$ & $\ldots$ & $\ldots$ & $\ldots$ & $\ldots$ & $\ldots$ & $\ldots$ & 15 \\
\hline 23 & $\ldots$ & $\ldots$ & 1 & $\ldots$ & $\ldots$ & $\ldots$ & $\ldots$ & $\ldots$ & $\ldots$ & $\ldots$ & 1 \\
\hline 24 & $\ldots$ & $\ldots$ & 2 & $\ldots$ & $\ldots$ & $\ldots$ & $\ldots$ & $\ldots$ & $\ldots$ & $\ldots$ & 2 \\
\hline 28 & $\ldots$ & $\ldots$ & 1 & $\ldots$ & $\ldots$ & $\ldots$ & $\ldots$ & $\ldots$ & $\ldots$ & $\ldots$ & 1 \\
\hline 29 & $\ldots$ & $\ldots$ & $\ldots$ & $\ldots$ & 1 & 1 & $\ldots$ & $\ldots$ & $\ldots$ & $\ldots$ & 2 \\
\hline 32 & $\ldots$ & 1 & 1 & $\ldots$ & $\ldots$ & 2 & $\ldots$ & $\ldots$ & $\ldots$ & $\ldots$ & 4 \\
\hline 33 & $\ldots$ & $\ldots$ & 1 & $\ldots$ & $\ldots$ & $\ldots$ & $\ldots$ & $\ldots$ & $\ldots$ & $\ldots$ & 1 \\
\hline 34 & $\ldots$ & 1 & 29 & $\ldots$ & $\ldots$ & $\ldots$ & $\ldots$ & $\ldots$ & $\ldots$ & $\ldots$ & 30 \\
\hline 36 & $\ldots$ & 8 & 27 & $\ldots$ & $\ldots$ & $\ldots$ & $\ldots$ & $\ldots$ & $\ldots$ & $\ldots$ & 35 \\
\hline 38 & $\ldots$ & 2 & 19 & 1 & $\ldots$ & 1 & $\ldots$ & $\ldots$ & $\ldots$ & $\ldots$ & 23 \\
\hline 39 & $\ldots$ & 1 & 1 & $\ldots$ & $\ldots$ & $\ldots$ & $\ldots$ & $\ldots$ & $\ldots$ & $\ldots$ & 2 \\
\hline 40 & $\ldots$ & $\ldots$ & 1 & $\ldots$ & $\ldots$ & $\ldots$ & $\ldots$ & $\ldots$ & $\ldots$ & $\ldots$ & 1 \\
\hline 44 & $\ldots$ & $\ldots$ & 3 & $\ldots$ & 1 & $\ldots$ & $\ldots$ & $\ldots$ & $\ldots$ & $\ldots$ & 4 \\
\hline 48 & $\ldots$ & $\ldots$ & $\ldots$ & $\ldots$ & 1 & 1 & $\ldots$ & $\ldots$ & $\ldots$ & $\ldots$ & 2 \\
\hline 49 & $\ldots$ & 3 & 10 & $\ldots$ & $\ldots$ & $\ldots$ & $\ldots$ & $\ldots$ & $\ldots$ & $\ldots$ & 13 \\
\hline 56 & $\ldots$ & $\ldots$ & 68 & 4 & 8 & $\ldots$ & $\ldots$ & $\ldots$ & 1 & 1 & 82 \\
\hline 59 & $\ldots$ & $\ldots$ & 3 & $\ldots$ & 1 & $\ldots$ & $\ldots$ & $\ldots$ & $\ldots$ & $\ldots$ & 4 \\
\hline 65 & $\ldots$ & $\ldots$ & 1 & $\ldots$ & $\ldots$ & $\ldots$ & $\ldots$ & $\ldots$ & $\ldots$ & $\ldots$ & 1 \\
\hline 68 & $\ldots$ & $\ldots$ & 2 & $\ldots$ & $\ldots$ & $\ldots$ & $\ldots$ & $\ldots$ & $\ldots$ & $\ldots$ & 2 \\
\hline 69 & $\ldots$ & $\ldots$ & 2 & $\ldots$ & $\ldots$ & $\ldots$ & $\ldots$ & $\ldots$ & $\ldots$ & $\ldots$ & 2 \\
\hline 83 & $\ldots$ & $\ldots$ & $\ldots$ & $\ldots$ & $\ldots$ & $\ldots$ & $\ldots$ & $\ldots$ & 2 & $\ldots$ & 2 \\
\hline 87 & $\ldots$ & $\ldots$ & $\ldots$ & $\ldots$ & $\ldots$ & 1 & $\ldots$ & $\ldots$ & $\ldots$ & $\ldots$ & 1 \\
\hline 88 & $\ldots$ & $\ldots$ & 1 & $\ldots$ & $\ldots$ & $\ldots$ & $\ldots$ & $\ldots$ & $\ldots$ & $\ldots$ & 1 \\
\hline 96 & $\ldots$ & $\ldots$ & 1 & $\ldots$ & $\ldots$ & $\ldots$ & $\ldots$ & $\ldots$ & $\ldots$ & $\ldots$ & 1 \\
\hline 97 & $\ldots$ & $\ldots$ & 1 & $\ldots$ & $\ldots$ & $\ldots$ & $\ldots$ & $\ldots$ & $\ldots$ & $\ldots$ & 1 \\
\hline 98 & $\ldots$ & $\ldots$ & $\ldots$ & 1 & 1 & $\ldots$ & $\ldots$ & $\ldots$ & $\ldots$ & $\ldots$ & 2 \\
\hline 102 & $\ldots$ & $\ldots$ & $\ldots$ & $\ldots$ & $\ldots$ & $\ldots$ & 1 & $\ldots$ & $\ldots$ & $\ldots$ & 1 \\
\hline 104 & $\ldots$ & 1 & 1 & $\ldots$ & $\ldots$ & $\ldots$ & $\ldots$ & $\ldots$ & $\ldots$ & $\ldots$ & 2 \\
\hline 105 & $\ldots$ & 1 & $\ldots$ & $\ldots$ & $\ldots$ & $\ldots$ & $\ldots$ & $\ldots$ & $\ldots$ & $\ldots$ & 1 \\
\hline 107 & $\ldots$ & $\ldots$ & 2 & $\ldots$ & $\ldots$ & $\ldots$ & $\ldots$ & $\ldots$ & $\ldots$ & $\ldots$ & 2 \\
\hline 109 & $\ldots$ & $\ldots$ & 1 & $\ldots$ & $\ldots$ & $\ldots$ & $\ldots$ & $\ldots$ & $\ldots$ & $\ldots$ & 1 \\
\hline 111 & $\ldots$ & 1 & $\ldots$ & 1 & $\ldots$ & $\ldots$ & 1 & $\ldots$ & $\ldots$ & $\ldots$ & 3 \\
\hline 113 & $\ldots$ & $\ldots$ & $\ldots$ & $\ldots$ & $\ldots$ & 1 & 2 & 3 & $\ldots$ & $\ldots$ & 6 \\
\hline 116 & $\ldots$ & $\ldots$ & $\ldots$ & $\ldots$ & 1 & $\ldots$ & $\ldots$ & $\ldots$ & $\ldots$ & $\ldots$ & 1 \\
\hline 117 & $\ldots$ & $\ldots$ & 1 & $\ldots$ & $\ldots$ & $\ldots$ & $\ldots$ & $\ldots$ & $\ldots$ & $\ldots$ & 1 \\
\hline 122 & $\ldots$ & 1 & 1 & $\ldots$ & $\ldots$ & $\ldots$ & $\ldots$ & $\ldots$ & $\ldots$ & $\ldots$ & 2 \\
\hline 125 & $\ldots$ & $\ldots$ & $\ldots$ & 1 & $\ldots$ & $\ldots$ & $\ldots$ & $\ldots$ & $\ldots$ & $\ldots$ & 1 \\
\hline 136 & $\ldots$ & $\ldots$ & 1 & $\ldots$ & $\ldots$ & $\ldots$ & $\ldots$ & $\ldots$ & $\ldots$ & $\ldots$ & 1 \\
\hline 139 & $\ldots$ & $\ldots$ & 1 & $\ldots$ & 1 & $\ldots$ & $\ldots$ & $\ldots$ & $\ldots$ & $\ldots$ & 2 \\
\hline 140 & $\ldots$ & $\ldots$ & 1 & $\ldots$ & $\ldots$ & $\ldots$ & $\ldots$ & $\ldots$ & $\ldots$ & $\ldots$ & 1 \\
\hline 142 & $\ldots$ & $\ldots$ & $\ldots$ & $\ldots$ & $\ldots$ & 1 & $\ldots$ & $\ldots$ & $\ldots$ & $\ldots$ & 1 \\
\hline 146 & $\ldots$ & $\ldots$ & 1 & $\ldots$ & $\ldots$ & $\ldots$ & $\ldots$ & $\ldots$ & $\ldots$ & $\ldots$ & 1 \\
\hline 147 & $\ldots$ & $\ldots$ & 5 & $\ldots$ & $\ldots$ & $\ldots$ & $\ldots$ & $\ldots$ & $\ldots$ & $\ldots$ & 5 \\
\hline 151 & $\ldots$ & $\ldots$ & $\ldots$ & $\ldots$ & $\ldots$ & 3 & 1 & $\ldots$ & 1 & 13 & 18 \\
\hline 153 & $\ldots$ & $\ldots$ & $\ldots$ & $\ldots$ & $\ldots$ & $\ldots$ & 1 & $\ldots$ & $\ldots$ & $\ldots$ & 1 \\
\hline No. isolates & 3 & 22 & 284 & 15 & 25 & 28 & 12 & 3 & 13 & 21 & 426 \\
\hline No. races & 3 & 12 & 38 & 8 & 10 & 11 & 7 & 1 & 6 & 5 & $\ldots$ \\
\hline
\end{tabular}


The overall race structure and diversity of the uredinial populations varied considerably from 1912 to 2002 (Table 4). Race 56 was the most common race in uredinial collections from wheat in the 1930s and
1940 s, but it was largely replaced by race 15 in the 1950 s. Race 15 was consistently the predominant race from 1950 to 1999. By the 1990s, race 151 had increased to a frequency nearly as great as that of race
15, and from 2000 to 2002 race 151 represented $89 \%$ of the races found in uredinial collections (Table 4).

Our simulations with sample sizes of 20 , $40,80,160$, and 320 drawn at random

Table 3. Most common races of Puccinia graminis f. sp. tritici identified in aecial and uredinial collections in Minnesota from 1912 to $2002^{\mathrm{a}}$

\begin{tabular}{|c|c|c|c|c|c|c|c|c|}
\hline \multirow[b]{2}{*}{ Time periods } & \multicolumn{4}{|c|}{ Aecial isolates } & \multicolumn{4}{|c|}{ Uredinial isolates } \\
\hline & No. of isolates & & Most comm & & No. of isolates & & ommo & \\
\hline $1912-1919$ & $3^{\mathrm{b}}$ & 11 & 17 & 19 & 50 & 19 & 12 & 3 \\
\hline $1920-1929$ & 22 & 36 & 49 & 38 & 309 & 36 & 21 & 49 \\
\hline 1930-1939 & 284 & 56 & 17 & $11,34^{\mathrm{c}}$ & 778 & 56 & 36 & 49 \\
\hline 1940-1949 & 15 & 56 & 17 & 15 & 684 & 56 & 17 & 38 \\
\hline $1950-1959$ & 25 & 56 & 15 & 11 & 698 & 15 & 56 & 11 \\
\hline 1960-1969 & 28 & 15 & 11 & 151 & 1,120 & 15 & 56 & 11 \\
\hline 1970-1979 & 12 & 15 & 113 & $\ldots$ & 1,175 & 15 & 151 & 11 \\
\hline 1980-1989 & $3^{b}$ & 113 & $\ldots$ & $\ldots$ & 631 & 15 & 151 & 17 \\
\hline 1990-1999 & 13 & 11 & 16 & 83 & 251 & 15 & 151 & 294 \\
\hline $2000-2002$ & 20 & 151 & 11 & 15,16 & 181 & 151 & 11 & 15 \\
\hline
\end{tabular}

${ }^{a}$ Races $15 \mathrm{~B}$ and 15B-2, which were distinguished from race 15 by the use of supplemental differentials beginning in the 1940s, are included here with race 15 for consistency throughout the survey period from 1912 to 2002. For the same reason, race 17A is included with race 17. There were several races with just one isolate each (indicated by ...), including races 11 and 151 .

${ }^{\text {b }}$ Only three aecial isolates of $P$. graminis f. sp. tritici were collected from 1912 to 1919 and from 1980 to 1989 . In 1912 to 1919 , there was one isolate each or races 11, 17, and 19; in 1980-1989 all three isolates were of race 113.

c There were 29 isolates each of race 11 and race 34, the third most common races in 1930 to 1939.

Table 4. Numbers of isolates and races of Puccinia graminis f. sp. tritici found per decade in collections of uredinia from Minnesota from 1912 to 2002

\begin{tabular}{|c|c|c|c|c|c|c|c|c|c|c|c|}
\hline \multirow[b]{2}{*}{ Race } & \multicolumn{10}{|c|}{ Decade } & \multirow[b]{2}{*}{ Tota } \\
\hline & 1912-1919 & 1920-1929 & 1930-1939 & 1940-1949 & 1950-1959 & 1960-1969 & 1970-1979 & 1980-1989 & 1990-1999 & $2000-2002$ & \\
\hline 1 & 2 & 6 & 2 & $\ldots$ & $\ldots$ & $\ldots$ & $\ldots$ & $\ldots$ & $\ldots$ & $\ldots$ & 10 \\
\hline 3 & 5 & 8 & $\ldots$ & $\ldots$ & $\ldots$ & $\cdots$ & $\ldots$ & $\ldots$ & $\ldots$ & $\ldots$ & 13 \\
\hline 5 & 3 & $\ldots$ & $\cdots$ & $\cdots$ & $\ldots$ & $\ldots$ & $\ldots$ & $\ldots$ & $\ldots$ & $\ldots$ & 3 \\
\hline 9 & $\ldots$ & 7 & $\ldots$ & $\ldots$ & $\ldots$ & $\ldots$ & $\ldots$ & $\ldots$ & $\ldots$ & $\ldots$ & 7 \\
\hline 11 & 4 & 28 & 47 & 3 & 31 & 82 & 38 & $\ldots$ & 8 & 18 & 259 \\
\hline 12 & 6 & $\ldots$ & $\ldots$ & $\ldots$ & $\ldots$ & $\ldots$ & $\ldots$ & $\ldots$ & $\ldots$ & $\ldots$ & 6 \\
\hline 13 & 2 & $\ldots$ & $\ldots$ & $\ldots$ & $\ldots$ & $\ldots$ & $\ldots$ & $\ldots$ & $\ldots$ & $\ldots$ & 2 \\
\hline 14 &.. & $\ldots$ & 3 & $\ldots$ & $\ldots$ & $\ldots$ & $\ldots$ & $\ldots$ & $\ldots$ & $\ldots$ & 3 \\
\hline 15 & 1 & 2 & 5 & 3 & 475 & 560 & 860 & 574 & 92 & 4 & 2,576 \\
\hline 17 & 4 & 29 & 36 & 236 & 15 & 31 & 3 & 7 & $\ldots$ & $\ldots$ & 361 \\
\hline 18 & 2 & 18 & $\ldots$ & $\ldots$ & $\ldots$ & $\ldots$ & $\ldots$ & $\ldots$ & $\ldots$ & $\ldots$ & 20 \\
\hline 19 & 9 & 19 & 11 & 24 & $\ldots$ & $\ldots$ & $\ldots$ & $\ldots$ & $\ldots$ & $\ldots$ & 63 \\
\hline 21 & 1 & 39 & 26 & $\ldots$ & $\ldots$ & $\ldots$ & $\ldots$ & $\ldots$ & $\ldots$ & $\ldots$ & 66 \\
\hline 23 & $\ldots$ & 8 & 1 & $\ldots$ & $\ldots$ & 1 & $\ldots$ & $\ldots$ & $\ldots$ & $\ldots$ & 10 \\
\hline 24 & 4 & 6 & $\ldots$ & $\ldots$ & $\ldots$ & $\ldots$ & $\ldots$ & $\ldots$ & $\ldots$ & $\ldots$ & 10 \\
\hline 29 & 2 & 10 & $\ldots$ & $\ldots$ & 12 & 28 & 1 & $\ldots$ & $\cdots$ & $\ldots$ & 53 \\
\hline 30 & 1 & 16 & $\ldots$ & $\cdots$ & $\ldots$ & $\ldots$ & $\ldots$ & $\ldots$ & $\ldots$ & $\ldots$ & 17 \\
\hline 31 & $\ldots$ & $\ldots$ & $\ldots$ & $\ldots$ & $\ldots$ & $\ldots$ & 1 & $\ldots$ & $\ldots$ & $\ldots$ & 1 \\
\hline 32 & 4 & $\ldots$ & $\ldots$ & $\ldots$ & $\ldots$ & 25 & 28 & $\cdots$ & $\cdots$ & $\cdots$ & 57 \\
\hline 34 & $\ldots$ & 2 & 58 & 2 & 6 & $\ldots$ & $\ldots$ & $\ldots$ & $\ldots$ & $\ldots$ & 68 \\
\hline 36 & $\ldots$ & 50 & 94 & 10 & $\ldots$ & $\ldots$ & $\ldots$ & $\ldots$ & $\ldots$ & $\ldots$ & 154 \\
\hline 37 & $\ldots$ & 4 & $\ldots$ & $\ldots$ & $\ldots$ & $\ldots$ & $\ldots$ & $\ldots$ & $\ldots$ & $\ldots$ & 4 \\
\hline 38 & $\ldots$ & 18 & 75 & 43 & 1 & 10 & $\ldots$ & $\ldots$ & $\ldots$ & $\ldots$ & 147 \\
\hline 39 & $\ldots$ & 1 & $\ldots$ & $\ldots$ & 1 & $\ldots$ & $\ldots$ & $\ldots$ & $\ldots$ & $\ldots$ & 2 \\
\hline 40 & $\ldots$ & $\ldots$ & $\ldots$ & 1 & 1 & $\ldots$ & $\ldots$ & $\ldots$ & $\ldots$ & $\ldots$ & 2 \\
\hline 48 & $\begin{array}{l}\cdots \\
\ldots\end{array}$ & $\cdots$ & $\cdots$ & $\ldots$ & 3 & 6 & $\begin{array}{l}\cdots \\
\ldots\end{array}$ & $\begin{array}{l}\cdots \\
\cdots\end{array}$ & $\begin{array}{l}\cdots \\
\cdots\end{array}$ & $\cdots$ & 9 \\
\hline 49 & $\ldots$ & 36 & 65 & 4 & $\ldots$ & $\ldots$ & $\ldots$ & $\ldots$ & $\ldots$ & $\ldots$ & 105 \\
\hline 52 & $\ldots$ & 1 & 1 & $\ldots$ & 1 & $\ldots$ & $\ldots$ & $\ldots$ & $\ldots$ & $\ldots$ & 3 \\
\hline 55 & $\ldots$ & $\ldots$ & $\ldots$ & 1 & $\ldots$ & $\ldots$ & $\ldots$ & $\begin{array}{l}\cdots \\
\cdots\end{array}$ & $\begin{array}{l}\cdots \\
\cdots\end{array}$ & $\begin{array}{l}\cdots \\
\ldots\end{array}$ & 1 \\
\hline 56 & $\ldots$ & 1 & 341 & 357 & 149 & 341 & 7 & 3 & $\ldots$ & 1 & 1200 \\
\hline 59 & $\ldots$ & $\ldots$ & 2 & $\ldots$ & 1 & 1 & $\ldots$ & $\ldots$ & $\ldots$ & $\ldots$ & 4 \\
\hline 61 & $\ldots$ & $\ldots$ & 3 & $\ldots$ & $\ldots$ & $\ldots$ & $\ldots$ & $\ldots$ & $\ldots$ & $\ldots$ & 3 \\
\hline 64 & $\ldots$ & $\ldots$ & 2 & $\ldots$ & $\ldots$ & $\ldots$ & $\ldots$ & $\ldots$ & $\ldots$ & $\ldots$ & 2 \\
\hline 65 & $\ldots$ & $\ldots$ & 1 & $\ldots$ & $\ldots$ & $\ldots$ & $\ldots$ & $\ldots$ & $\ldots$ & $\ldots$ & 1 \\
\hline 87 & $\ldots$ & $\ldots$ & $\ldots$ & $\ldots$ & $\ldots$ & 5 & $\ldots$ & $\ldots$ & $\ldots$ & $\ldots$ & 5 \\
\hline 113 & $\ldots$ & $\ldots$ & $\ldots$ & $\ldots$ & $\ldots$ & 2 & 36 & 4 & 5 & $\ldots$ & 47 \\
\hline 125 & $\ldots$ & $\ldots$ & 3 & $\ldots$ & 1 & $\ldots$ & $\ldots$ & $\ldots$ & $\ldots$ & $\ldots$ & 4 \\
\hline 139 & $\ldots$ & $\ldots$ & 2 & $\ldots$ & 1 & $\ldots$ & $\ldots$ & $\ldots$ & $\ldots$ & $\ldots$ & 3 \\
\hline 142 & $\ldots$ & $\ldots$ & $\ldots$ & $\ldots$ & $\ldots$ & $\ldots$ & 1 & $\ldots$ & $\ldots$ & $\ldots$ & 1 \\
\hline 151 & $\ldots$ & $\ldots$ & $\ldots$ & $\ldots$ & $\begin{array}{l}\cdots \\
\ldots\end{array}$ & 28 & 197 & 43 & 80 & 158 & 506 \\
\hline 210 & $\ldots$ & $\ldots$ & $\ldots$ & $\ldots$ & $\ldots$ & $\ldots$ & 3 & $\ldots$ & $\ldots$ & $\ldots$ & 3 \\
\hline 294 & $\ldots$ & $\ldots$ & $\ldots$ & $\ldots$ & $\ldots$ & $\ldots$ & $\ldots$ & $\ldots$ & 66 & $\ldots$ & 66 \\
\hline No. isolates & 50 & 309 & 778 & 684 & 698 & 1,120 & 1,175 & 631 & 251 & 181 & 5,877 \\
\hline No. races & 15 & 21 & 20 & 11 & 14 & 13 & 11 & 5 & 5 & 4 & $\ldots$ \\
\hline
\end{tabular}


from the data for 698 uredinial isolates from the 1950s revealed that values for the normalized Shannon Index of Diversity tended to be higher for smaller samples in the range of 20 to 80 individuals (data not shown). Most aecial collections had sample sizes near 20, whereas most uredinial collections had more than 300 isolates. Thus, comparisons of diversity between aecial and uredinial isolates were biased toward higher diversity values for aecial isolates. However, even the adjusted normalized Shannon Index of Diversity values based on random samples of 20 isolates from uredinial populations showed less diversity in uredinial populations than aecial populations after 1930 (Fig. 1). The unadjusted Shannon Index of Diversity for aecial isolates in the 1930s appears to be low compared with other decades, but there were 284 aecial isolates in the 1930 s. Adjusting this value for a sample size of 20 gives an adjusted diversity index of 0.69 , which is similar to the diversity values calculated for aecial isolates from the 1920s and 1940s and greater than the adjusted diversity for uredinial isolates in the 1930s. Diversity among uredinial populations declined steadily from 1920 to 1959 (Fig. 1), after which it fluctuated at levels below those in the aecial populations. There were too few aecial isolates from the 1980s or from 1912 to 1919 for meaningful comparisons with the uredinial populations in those years.

\section{DISCUSSION}

Important changes in the $P$. graminis population have occurred over the 90 -year period since the initiation of the Barberry Eradication Program. Some of these changes may be a direct consequence of the removal of barberry from the proximity of wheat fields and others may relate more to changes in the genetic composition of the wheat host population. Epidemics of stem rust on wheat and yield losses due to stem rust in the spring wheat area of the northern Great Plains have declined significantly as a result of eliminating vast numbers of barberry bushes and deploying wheat cultivars with genes conferring resistance to the dominant $P$. graminis f. sp. tritici races (13).

The most obvious changes in aecial populations relate to changes in the predominant forma speciales found colonizing barberry. The general picture shows an early abundance of $P$. graminis f. sp. tritici isolates before and immediately after the initiation of barberry eradication (1912 to 1929), followed by a period from 1930 to 1989 when $P$. graminis f. sp. secalis was more common than $P$. graminis f. sp. tritici, especially after 1970. These changes, set against the backdrop of a general decline in numbers of aecial collections, may indicate that $P$. graminis $\mathrm{f}$. sp. tritici had become less able than $P$. graminis f. sp. secalis to infect barberry after the eradication of barberry bushes from the main wheat-producing regions of Minnesota. After 1990, however, the proportion of $P$. graminis f. sp. tritici among aecial collections increased dramatically and $P$. graminis f. sp. secalis declined.
The frequency of formae speciales does not correlate well with relative areas of cereal production in Minnesota during the years of this study (Fig. 2). Data indicate that, from the early years of barberry eradication (1920s and 1930s) through the

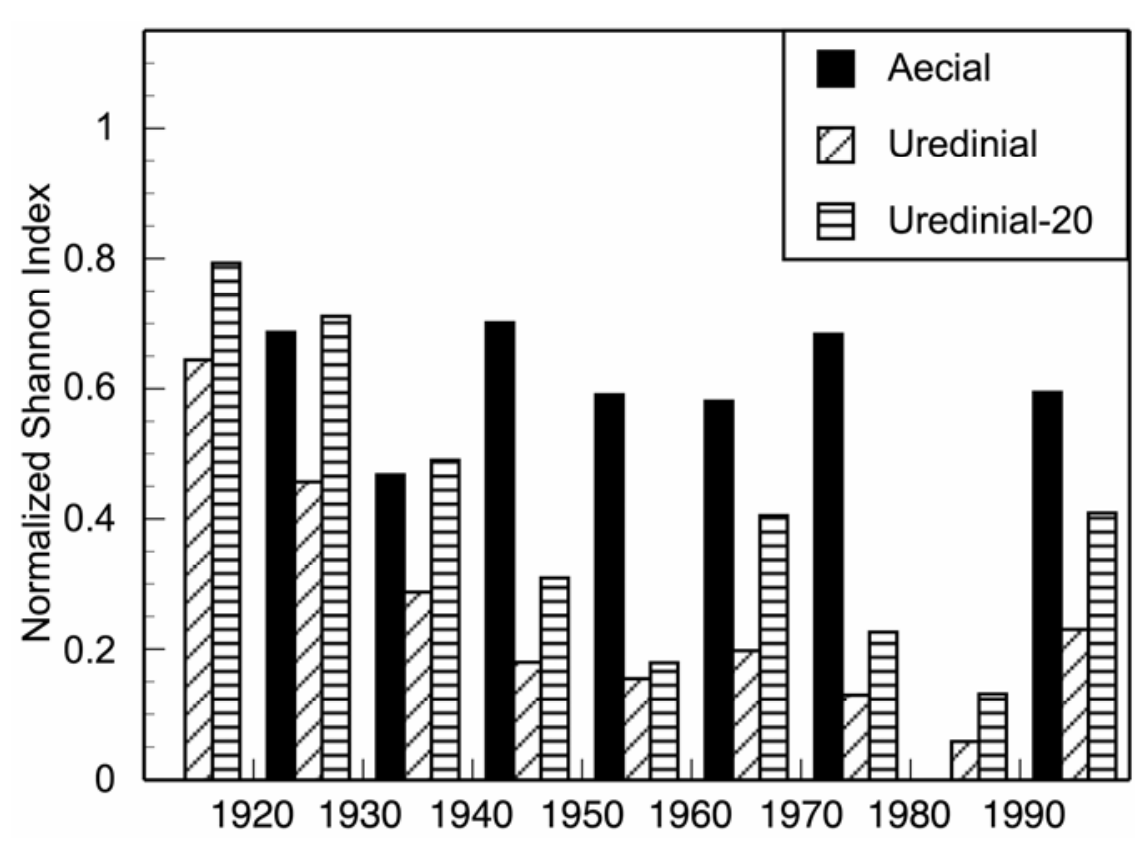

Fig. 1. Diversity among aecial and uredinial isolates of Puccinia graminis f. sp. tritici collected in Minnesota from 1912 to 1999, as calculated by the normalized Shannon Diversity Index. Diversity values were calculated for isolates collected from 1912 to 1919,1920 to 1929,1930 to 1939 , and so on. Data for collections in decades with fewer than 10 isolates are not shown (i.e., aecial isolates from 1912 to 1919 and 1980 to 1989). An adjusted index for uredinial isolates (Uredinial-20) is shown in addition to the calculated values of normalized Shannon Index. The adjusted value is the mean normalized Shannon Index from five simulations in which 20 uredinial isolates were chosen at random from the entire set of isolates for the calculations. The simulations were done to take into account the effect of sample size on normalized Shannon Index, because most aecial samples contained about 20 isolates, whereas most uredinial samples contained $>300$ isolates. Note: there were 284 aecial isolates in 1930 to 1939; the adjusted value of 0.69 (simulated sample size of 20) for aecial isolates in 1930 to 1939 is not shown in the graph.

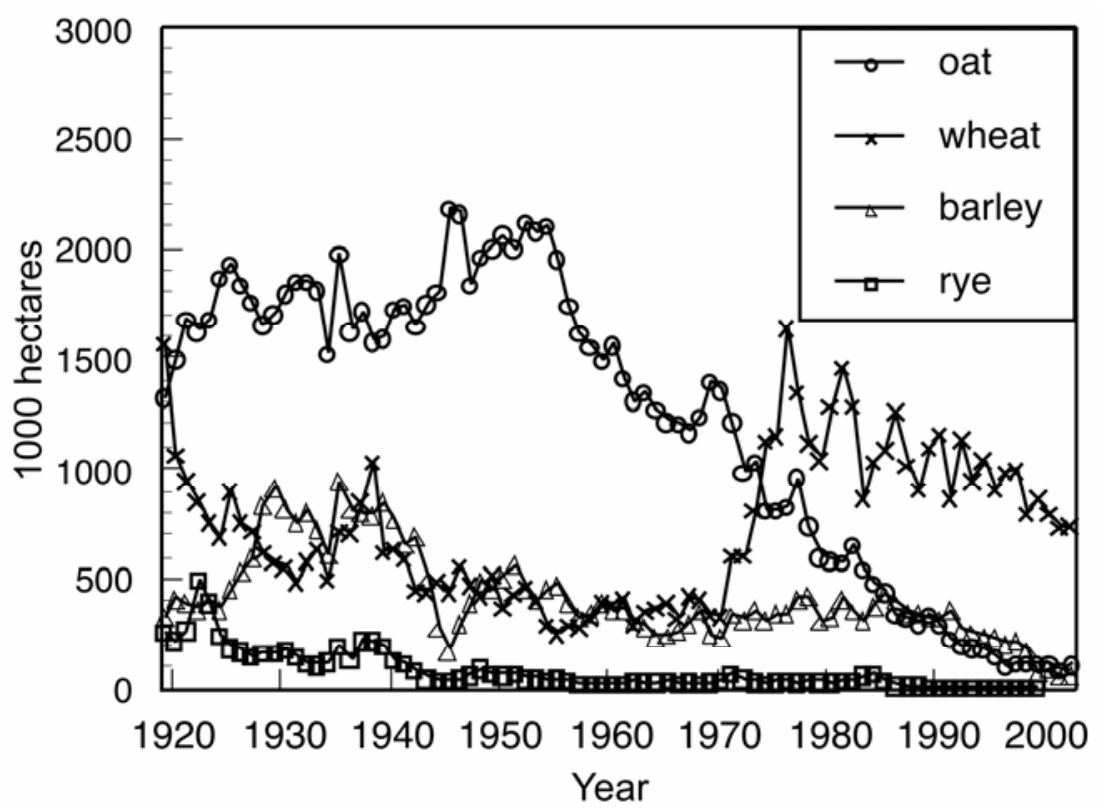

Fig. 2. Harvested acreage of cereal crops in Minnesota from 1918 to 2002. Data from 1918 to 1976 from Roelfs (12) and data from 1977 to 2002 from the United States Department of AgricultureAgricultural Research Service Cereal Disease Laboratory website (8). 
1960 s, oat was the predominant small grain in Minnesota $(8,12)$. Although the area planted to wheat in Minnesota exceeded that of barley in the 1920s, barley and wheat occupied similar areas from 1935 to 1971. After 1975, wheat became the predominant small grain grown in Minnesota (8). Throughout the survey, the total acreage of rye grown was small; hence, the predominance of $P$. graminis $\mathrm{f}$. sp. secalis isolates seems unusually high. However, the abundance of wild grasses in the close proximity to both grain fields and barberry bushes in areas far removed from the grain fields may help explain some of the population changes observed throughout the survey. Quackgrass (Elytrigia repens $=$ Agropyron repens) is a very abundant weedy grass in Minnesota (1) that is susceptible to stem rust (3) and often occurs in areas where barberry bushes still exist. Nearly all isolates of $P$. graminis from quackgrass during the surveys have been identified as $P$. graminis $\mathrm{f}$. sp. secalis. Thus, populations of $P$ graminis $\mathrm{f}$. sp. secalis could have been maintained in Minnesota as alternating uredinial, telial, and aecial populations on and around the remaining barberry bushes. Nearly all $P$. graminis isolates from cultivated barley, Hordeum vulgare, and wild foxtail barley, H. jubatum, until 1989 in Minnesota also were $P$. graminis f. sp. secalis. Both quackgrass and foxtail barley could have served as bridging hosts to carry isolates of $P$. graminis f. sp. secalis (3) across the distance from fields of cultivated barley to barberry bushes far removed from grain fields. This would help explain why $P$. graminis f. sp. secalis was more common than $P$. graminis f. sp. tritici in aecia on the barberry bushes that remained after eradication of barberry bushes from the vicinity of grain fields in the 1920s and 1930s. Since the mid-1970s, wheat has been the predominant small grain crop in Minnesota, with only small acreages of barley, oat, and rye. In addition, a new race of $P$. graminis f. sp. tritici found in the Great Plains in 1989 became common on both cultivated barley and foxtail barley in the 1990s (16). This change and the recent reemergence of barberry bushes in Minnesota (11) may be related to the increase in frequency of $P$. graminis $\mathrm{f}$. sp. tritici relative to $P$. graminis $\mathrm{f}$. sp. secalis isolates in aecial collections since 1990. All aecial isolates since 1975 have been collected in southeastern and east central districts of Minnesota (11), where very little wheat or barley production occurs. Therefore, teliospore inoculum of $P$. graminis from weedy hosts probably has played and still plays an important role in determining the predominant forma speciales and races present in aecial collections in Minnesota.

Roelfs (13) suggested that the removal of barberry as an alternate host had a pro- found effect on the genetic diversity and the stability of pathogenic races collected from wheat. Our data support this hypothesis as this relates to uredinial populations. However, the diversity of the aecial races remained essentially unchanged throughout most of the twentieth century. Although more than one million barberry bushes were destroyed during the course of the barberry eradication campaign in Minnesota (11), this appears to have had very little effect on the overall diversity of the isolates reproducing and colonizing barberry. Even as the numbers of isolates collected from barberry declined from the 1930s onward, the diversity of the aecial populations remained consistently greater than that of the uredinial populations. With sexual reproduction occurring on barberry, we would expect the diversity of races among aecial collections to be greater than among uredinial collections and different isolates to predominate in aecial collections than in uredinial collections. Although we observed a much higher level of diversity among aecial isolates, the predominant race in uredinial and aecial populations was the same in many of the decades studied. One explanation for this could be that many of the aecia could have been produced through selfing. If the virulence loci used to designate the races were homozygous in the predominant races of $P$. graminis f. sp. tritici occurring in the uredinial population, then selfing would result in progeny identical to the parent for these loci. Even if a few of the loci were heterozygous in the predominant races, a large proportion of the progeny would be identical or very similar to the parent if virulence was recessive and avirulence was dominant. A high degree of selfing would be expected if little genetic diversity occurred in the uredinial population and if the density of germinating teliospores was low. Selection pressure imposed by resistant wheat cultivars could have eliminated many aecial progeny if they lacked virulence necessary to infect the cultivars and lines that were grown in wheat fields and breeders' nurseries. Alternately, a small subpopulation of $P$. graminis $\mathrm{f}$. sp. tritici with increased fitness on common wild grasses as well as on susceptible wheat and barley cultivars may have developed in Minnesota in recent years. If such a subpopulation predominated on wild grasses around barberry bushes, this could account for the differences between predominant races of $P$. graminis f. $\mathrm{sp}$. tritici found in aecial compared with uredinial collections in Minnesota since 1980. Development of such a subpopulation also could account for the increased frequency of $P$. graminis f. sp. tritici among the aecial collections since 1990 .

\section{LITERATURE CITED}

1. Anonymous, 1971. Common Weeds of the United States. Dover Publication, New York.
2. Clark, R.V., Seaman, W. L., and Martens, J. W. 1986. Puccinia graminis on barberry and oats in eastern Ontario from 1968 to 1983 . Can. J. Plant Pathol. 8:193-200.

3. Fischer, G. W., and Levine, M. N. 1941. Summary of the recorded data on the reaction of wild and cultivated grasses to stem rust ( $P u c$ cinia graminis), leaf rust (P. rubigo-vera), stripe rust ( $P$. glumarum), and crown rust $(P$ coronata) in the United States and Canada. Plant Dis. Rep. Suppl. 130.

4. Groth, J. V., and Roelfs, A. P. 1982. Effect of sexual and asexual reproduction on the race abundance in cereal rust fungus populations. Phytopathology 72:1503-1507.

5. Groth, J. V., and Roelfs, A. P. 1987. The concept and measurement of phenotypic diversity in Puccinia graminis on wheat. Phytopathology 77:1395-1399.

6. Lebeda, A. 1982. Measurement of genetic diversity of virulence in populations of phytopathogenic fungi. Z. Pflanzenkrankh. Pflanzenschutz 89:88-95

7. Leonard, K. J. 2001. Stem rust-future enemy? Pages 119-146 in: Stem Rust of Wheat: From Ancient Enemy to Modern Foe. P. D. Peterson, ed. American Phytopathological Society, St. Paul, MN.

8. Long, D. L., and Hughes, M. E. 2003. Small grain losses to rust. U. S. Dep. Agric.-Agric Res. Serv. Cereal Disease Laboratory online publication CDL-EP\#007, updated annually.

9. Martens, J.W., Clark, R. V., and Seaman, W. L. 1985. Virulence combinations in sexually and asexually reproducing populations of Puccinia graminis avenae in Canada. Can. J. Plant Pathol. 7:127-131.

10. Peterson, P. D. 2003. The common barberry: the past and present situation in Minnesota and the risk of wheat stem rust epidemics. Ph.D. thesis, North Carolina State University, Raleigh.

11. Peterson, P. D., Leonard, K. J., Miller, J. D., Laudon, R. J., and Sutton, T. B. 2005. Prevalence and distribution of common barberry, the alternate host of Puccinia graminis, in Minnesota. Plant Dis. 89:159-163.

12. Roelfs, A. P., 1978. Estimated losses caused by rust in small grain cereals in the United States-1918-76. U.S. Dep. Agric. Misc. Publ. 1363.

13. Roelfs, A. P. 1982. Effects of barberry eradication on stem rust in the United States. Plant Dis. 72:177-181.

14. Roelfs, A. P, and Groth, J. V. 1980. A comparison of virulence phenotypes in wheat stem rust populations reproducing sexually and asexually. Phytopathology 70:855-862.

15. Roelfs, A. P., and Martens, J. W. 1988. An international system of nomenclature for Puccinia graminis f. sp. tritici. Phytopathology 78:526-533.

16. Roelfs, A. P., McCallum, B., McVey, D.V., and Groth, J. V. 1997. Comparison of virulence and isozyme phenotypes of Pgt-QCCJ and Great Plains races of Puccinia graminis f. sp. tritici. Phytopathology 87:910-914.

17. Sheldon, A. L. 1969. Equitability indices: Dependence on the species count. Ecology 50:466-467.

18. Stakman, E. C., and Harrar, J. G. 1957. Principles of Plant Pathology. Ronald Press Co., New York.

19. Stakman, E. C., and Levine, M. N. 1922. The determination of biologic forms of Puccinia graminis on Triticum spp. Minn. Agric. Exp. Stn. Tech. Bull. 8:1-10.

20. Stakman, E. C., Stewart, D. M., and Loegering, W. Q. 1962. Identification of physiologic races of Puccinia graminis var. tritici. U.S. Dep. Agric.-Agric. Res. Serv. Publ. E617. 